\title{
Effects of Aqueous Stem Bark Extract of Prosopis africana on Wistar Strain Rats
}

\author{
M. I. Bello ${ }^{1}$, M. A. Madusolumuo ${ }^{2}$, I. Igbokwe ${ }^{3}$ \\ ${ }^{1,2}$ Department of Biochemistry Modibbo Adama University of Technology, P.M.B. 2076 Yola, Nigeria \\ ${ }^{3}$ Department of Veterinary Medicine University of Maiduguri P.M.B.1059 Maiduguri, Nigeria
}

\begin{abstract}
Aqueous stem bark extract of Prosopis africana was subjected to phytochemical screening indicating the presence of alkaloids, tannins, anthraquinones, saponins and phenols. Antimicrobial susceptibility test of the aqueous stem bark extract using Escherichia coli, Streptococcus pneumoniae, Staphylococcus aureus and Klebsiella pneumoniae as test organisms showed varying zones of inhibition with $15 \mathrm{~mm}$ zone of inhibition exhibited by Staphylococcus aureus and Klebsiella pneumoniae respectively and 10mm zone of inhibition exhibited by Escherichia coli. Minimum Inhibitory Concentration (MIC) and Minimum Bactericidal Concentration (MBC) of extract were $16 \mu \mathrm{g} / \mathrm{ml}$ and $64 \mu \mathrm{g} / \mathrm{ml}$ respectively. Treatment of experimental animals with the aqueous stem bark extract for a period of six weeks and subsequent assessment of its effect biochemically showed that alanine aminotransferase (ALT), acid phosphatase (ACP) and lactate dehydrogenase (LDH) levels were significantly higher than normal suggesting certain degree of liver injury. Glucose, cholesterol, total and direct bilirubin as well as total protein levels were significantly higher than normal values with respect to animals that received the highest dose suggesting a dose dependent effects of the extract on the animals. Urea and creatinine levels were significantly higher than normal suggesting certain degree of leakage from the kidneys. Overall, the result of this work showed that the effects of the extract were more pronounced on the liver than the kidney as observed in the histological analyses of the tissues.
\end{abstract}

Keywords: Stem bark, Prosopis africana, zone of inhibition, dose dependent and histological

\section{Introduction}

Trees, shrubs and herbs have commonly been used in traditional medicine especially in developing countries (Sofowora, 1982). In many cultures there is this popular belief that "every plant grown on the surface of the earth has a medicinal property or use". However, it is impossible to provide a complete list of these uses to which most of these plants may be put (Bojang, 2000). Despite all the progress in synthetic chemistry and biotechnology, plants are still an indispensable source of medicinals, both preventive and curative. Hundreds of species of plants are recognized as having medicinal value, and many of them are commonly used to treat or prevent ailments and diseases .The medicinal properties of plants are often associated with one or all of the parts of the plant that include bark, leaf, flower, fruit, root or seed (Srivastava et al.,1996)

\section{Prosopis africana (Guill. and Perr.)}

Local names: Kirya (Hausa); Kohi (Fulfulde); Ayan (Yoruba); Sanchi lati (Nupe); Ubwa (Igbo); Kpaye (Tiv). This plant belongs to the family Mimosaceae.

Prosopis africana_is a savanna tree of about 12-18m high and up to $1 \mathrm{~m}$ in girth which may be readily distinguished by its dark rough bark, pale drooping foliage with small pointed leaflets and sausage-shaped fruits. The flowers which usually appear around December - May are yellowish, fragrant and densely crowded in fat spikes about $4-6 \mathrm{~cm}$ long excluding the shoot stalk

\section{Materials and Methods}

Stem bark sample of Prosopis africana was collected from within the premises of Modibbo Adama University of Technology Yola, Nigeria. The plant was identified at the Forestry Department of School of Agriculture and
Agricultural Technology, Modibbo Adama University of Technology Yola, Nigeria.

The plant specimen was washed with tap water and then dried in an oven at $50^{\circ} \mathrm{C}$ over a $72 \mathrm{~h}$ period. The dried sample was cut into small pieces with a clean knife and then ground to powder using mortar and pestle. Fifty (50g) grammes of powdered stem bark were soaked in $200 \mathrm{ml}$ of sterile distilled water, shaken and allowed to stand for 24 hours. The mixture was filtered using whatman No.1 $(115 \mathrm{~cm})$ filter paper. The filtrate was concentrated over a water bath at $50^{\circ} \mathrm{C}$. Dried extract was kept in sterile universal bottles and stored in a refrigerator for further use

Bacterial specimens were obtained from the microbiology laboratory of the Pathology Department of the Federal Medical Centre Yola Adamawa State, Nigeria. The test organisms were Klebsiella pneumoniae (Gram-negative rod), Escherichia coli (Gram-negative rod), Neisseria gonorrhoeae (Gram-negative cocci), and Staphylococcus aureus (Gram positive cocci). The test organisms were kept in slants of nutrient agar.

Male Wistar strain rats weighing between $100-150 \mathrm{~g}$ were purchased from the animal house National Veterinary Research Institute Vom in Jos, Plateau State Nigeria. The animals were stabilized using standard laboratory chaw. Twenty-five rats weighing 100 to $150 \mathrm{~g}$ were randomly divided into five groups of five rats each. Group 1 was the normal/control and groups 2, 3, 4, and 5 were administered daily with graded doses of 200,300,400 and $500 \mathrm{mg} / \mathrm{kg}$ body weight of the aqueous stem bark extract of Prosopis africana by intubation. Treatment was done for the period of six weeks. Experimental animals were fed ad libitum with laboratory chaw throughout the period of the study. 


\section{International Journal of Science and Research (IJSR) \\ ISSN (Online): 2319-7064}

Index Copernicus Value (2013): 6.14 | Impact Factor (2015): 6.391

The animals anaesthetised with diethyl-ether were sacrificed and the blood collected by cardiac puncture. The blood was allowed to clot, centrifuged for 10 minutes at 3000rpm in a desktop centrifuge. Serum was collected carefully with Pasteur pipette and transferred into clean sample bottles. The serum was used to determine serum levels of AST, ALT, LDH and ACP, alkaline phosphates, glucose, cholesterol, bilirubin (Total and Direct bilirubin), albumin, total protein, urea and creatinine. Livers of all the rats were removed and washed in $10 \%$ formal-saline and then fixed in fresh $10 \%$ formal saline. Livers of rats belonging to the same group were put in the same container. The same treatment was done for the kidney samples.

\section{Test for Alkaloids}

Test for alkaloids was carried out according to the methods described by Harborne (1973) and Trease and Evans (1978). Zero point five $(0.5 \mathrm{~g})$ grammes of each extract was stirred with $5 \mathrm{ml}$ of $1 \%$ aqueous hydrochloric acid on a steam bath before being filtered and $1 \mathrm{ml}$ of the filtrate was treated with a few drops of Mayer's reagent. A second $1 \mathrm{ml}$ portion was treated similarly with Dragendrorff's reagent. Turbidity or precipitation with either of these reagents was an evidence of the presence of alkaloids.

\section{Test for Saponins}

Test for saponins was done according to the method described by Wall et al., 1954. Zero point five $(0.5 \mathrm{~g})$ grammes of the extract was shaken with water in a test tube and frothing which persisted on warming indicated the presence of saponins. This is called frothing test. To confirm the presence of saponins, $0.5 \mathrm{~g}$ of the extract was boiled briefly with $50 \mathrm{ml}$ phosphate buffer $\mathrm{pH} 7.4$. The mixture was allowed to cool and after filtration about $5 \mathrm{ml}$ of the filtrate was passed (after 3 hours) through an asbestos disc $(1.5 \mathrm{~mm}$ thick and $7 \mathrm{~mm}$ in diameter) which had been previously soaked in 3 drops of $1 \%$ cholesterol in ether and dried. The disc was washed with $0.5 \mathrm{ml}$ distilled water. After drying, it was heated in $20 \mathrm{ml}$ of boiling oxylol for 2 hours in order to decompose the complex formed between cholesterol and any saponins. This disc was then washed in ether and after drying, it was placed on a $7 \%$ blood nutrient agar. Complete haemolysis of red blood cells around the disc after 6 hours was evidence of the presence of saponins.

\section{Test for Tannins}

Test for tannins was carried out according to the method described by Trease and Evans (1978). Five (5g) grammes of each portion of plant extract was stirred with $10 \mathrm{ml}$ of distilled water and then filtered and ferric chloride reagent added to the filtrate. A blue-black, green or blue-green precipitate indicated the presence of tannins.

\section{Test for phlobatannins}

Test for phlobatannins was carried out according to the method described by Trease and Evans (1978). Five (5ml) millilitres of the aqueous extract was mixed with $5 \mathrm{ml}$ of $1 \%$ aqueous hydrochloric acid and boiled. The appearance of a reddish green colour indicated the presence of phlobatannins.

\section{Test for Anthraquinones}

Test for anthraquinones was carried out according to the method described by Trease and Evans (1978). Borntrager's test was used for the detection of anthraquinones. Five $(5 \mathrm{~g})$ grammes of each plant extract were shaken with $10 \mathrm{ml}$ benzene. After filtration, $5 \mathrm{ml}$ of $10 \%$ ammonia solution was added to the filtrate, the mixture was shaken and the appearance of a pink, red, or violet colour in the ammoniacal (lower) phase indicated the presence of free anthraquinones.

For combined anthraquinones, $5 \mathrm{~g}$ of each plant extract was boiled with $10 \mathrm{ml}$ aqueous Sulphuric acid and filtered while hot. The filtrate was shaken with $5 \mathrm{ml}$ benzene and the benzene layer was separated and half its own volume of $10 \%$ ammonia solution added. The appearance of a pink, red, or violet colour in the ammoniacal (lower) phase indicated the presence of anthraquionone derivatives

\section{Test for Cardiac Glycosides}

\section{Legal Test}

The plant extract was dissolved in pyridine and a few drops of $2 \%$ sodium nitroprusside together with a few drops of $20 \% \mathrm{NaOH}$ added. The appearance of a deep red colour which faded to brownish yellow indicated the presence of cardenolides.

\section{Test for flavonoids}

Test for flavonoids was carried out according to the method described by Sofowora (1982). Five (5ml) millilitres of dilute ammonia solution was added to $0.5 \mathrm{~g}$ of the extract and $5 \mathrm{ml}$ of concentrated $\mathrm{H}_{2} \mathrm{SO}_{4}$ was added. A yellow colouration indicated the presence of flavonoids.

\section{Test for phenols}

Test for phenols was carried out according to method described by Trease and Evans (1978). Two (2ml) millilitres of Ferric chloride was added to $2 \mathrm{ml}$ the extract. A deep Blue-green colouration indicated the presence of phenols

\section{Quantitative determination of phytochemical components of the plant}

\section{Determination of total phenols by spectrophotometric method}

The fat free sample $(2 \mathrm{~g})$ was boiled with $50 \mathrm{ml}$ of ether for the extraction of the phenolic component for $15 \mathrm{~min}$. Five $\mathrm{ml}$ $(5 \mathrm{ml})$ of the extract was pipetted into a $50 \mathrm{ml}$ flask, then $10 \mathrm{ml}$ of distilled water was added. Two $\mathrm{ml}(2 \mathrm{ml})$ of ammonium hydroxide solution and $5 \mathrm{ml}$ of concentrated amyl alcohol were also added. The samples were made up to mark and left to react for $30 \mathrm{~min}$ for colour development. This was measured at $505 \mathrm{~nm}$.

\section{Determination of Alkaloids}

Alkaloids determination was done according to the method described by Harborne, 1973. About $5 \mathrm{~g}$ of the sample was weighed into a $250 \mathrm{ml}$ beaker and $200 \mathrm{ml}$ of $10 \%$ acetic acid in ethanol was added and covered and allowed to stand for 4hours. This was filtered and the extract was concentrated on a water bath to one-quarter of the original volume. 


\section{International Journal of Science and Research (IJSR) \\ ISSN (Online): 2319-7064 \\ Index Copernicus Value (2013): 6.14 | Impact Factor (2015): 6.391}

Concentrated ammonium hydroxide was added drop wise to the extract until the precipitation was complete. The whole solution was allowed to settle and the precipitate was collected and washed with dilute ammonium hydroxide and then filtered. The residue is the alkaloid, which was dried and weighed.

\section{Determination of Tannins}

The method described by Van-Burden and Robinson (1981) was used for the determination of tannins. A portion of $500 \mathrm{mg}$ of the sample was weighed into a $50 \mathrm{ml}$ plastic bottle. Fifty $(50 \mathrm{ml})$ millilitres of distilled water was added and shaken for 1 hour in a mechanical shaker. This was filtered into a $50 \mathrm{ml}$ volumetric flask and made up to the mark. Then $5 \mathrm{ml}$ of the filtrate was pipetted out into a test tube and mixed with $2 \mathrm{ml}$ of $0.1 \mathrm{M} \mathrm{FeCl}_{3}$ in $0 . \mathrm{IN} \mathrm{HCl}$ and $0.008 \mathrm{M}$ potassium ferrocyanide. The absorbance was measured at $120 \mathrm{~nm}$ within 10minutes.

\section{Determination of Saponins}

The method used was that of Obadoni and Ochuko (2001). The samples were ground and $20 \mathrm{~g}$ of the sample were put into a conical flask and $100 \mathrm{~cm}^{3}$ of $20 \%$ aqueous ethanol were added. The samples were heated over a hot water bath for 4 hours with continuous stirring at about $55^{\circ} \mathrm{C}$.

The mixture was filtered and the residue re-extracted with another $200 \mathrm{ml} 20 \%$ ethanol. The combined extracts were reduced to $40 \mathrm{ml}$ over water bath at about $90^{\circ} \mathrm{C}$. The concentrate was transferred into a $250 \mathrm{ml}$ separator funnel and $20 \mathrm{ml}$ of diethyl ether was added and shaken vigorously. The aqueous layer was recovered while the ether layer was discarded. The purification process was repeated. Sixty $(60 \mathrm{ml})$ millilitres of $\mathrm{n}$-butanol was added. The combined $\mathrm{n}$ butanol extracts were washed twice with $10 \mathrm{ml}$ of $5 \%$ aqueous sodium chloride. The remaining solution was heated in a waterbath. After evaporation the samples were dried in the oven to a constant weight; the saponin content was calculated as percentage.

\section{Determination of flavonoids}

Determination of flavonoids was done by the method described by Boham and Kocipai-Abyazan (1994). Ten $(10 \mathrm{~g})$ grammes of the plant sample were extracted repeatedly with $100 \mathrm{ml}$ of $80 \%$ aqueous methanol at room temperature. The whole solution was filtered through whatman filter No $42(125 \mathrm{~mm})$. The filtrate was later transferred into a crucible and evaporated in into dryness over a water bath and weighed to a constant weight.

\section{Determination of antimicrobial activity of the stem bark extract \\ Agar diffusion method described by Edward 1983 was used.}

Procedure: The paper discs were put into the extract whose concentration was $20 \mu \mathrm{g} / \mathrm{ml}$ and allowed to soak for some time. The discs were then removed and dried. The dried paper discs containing the absorbed extract were impregnated onto the surface of dried agar medium that has already been inoculated with the test organisms. These were left on the work bench for prediffusion and later incubated at $37^{\circ} \mathrm{c}$ for 18 to 24 hours. The plates were then observed and the diameter of zone of inhibition of growth was measured. Standard antibiotic discs of $20 \mu \mathrm{g} / \mathrm{ml}$ concentration were used in order to compare the zone of inhibition produced by both the crude extracts and standard antibiotic discs.

\section{Determination of Minimum Inhibitory and Minimum Bactericidal Concentrations of the plant extract}

Determination of Minimum Inhibitory and Minimum Bactericidal Concentrations were determined by the method described by Nester et al., 2004. Six test tubes containing serially diluted crude extracts in a nutrient broth were set The dilutions were $64,32,16,8,4$, and $0 \mu \mathrm{g} / \mathrm{ml}$ respectively, and the sixth test tube with $0 \mu \mathrm{g} / \mathrm{ml}$ served as the control. One (1ml) millilitre of test organism's suspension was introduced into each test tube and then incubated for 24 hours. The dilution was repeated with $32,16,8,4$, and $2 \mu \mathrm{g} / \mathrm{ml}$ respectively. The test tubes were incubated for 24hours and then observed for growth. The test tube having the lowest concentration of the extract that does not show any growth was considered the one with minimum inhibitory concentration (MIC).

The Minimum Bactericidal Concentration was determined by using those test tubes that do not show any growth in the MIC determination. One $\mathrm{ml}$ suspension of each of the test tubes that showed no growth was introduced into test tubes containing extract - free nutrient broth and incubated for 24hours. The test tubes were later observed for growth. Amongst the test tubes that do not show any growth, the one having the lowest concentration was regarded as the one with the minimum bactericidal concentration (MBC).

Table 1: Phytochemical components detected in the stem bark extract of Prosopis africana

\begin{tabular}{|c|c|c|c|c|c|c|c|c|}
\hline Alkaloids & Anthraquinones & Flavonoids & Phlobatannins & Phenols & Quinones & Saponins & Glycosides & Tannins \\
\hline+ & + & + & + & + & - & + & - & + \\
\hline
\end{tabular}

+= Presence of phytochemical component; - = Absence of phytochemical component.

Alkaloids, anthraquinones, flavonoids, phlobatannins, phenols, saponins, and tannins were detected in the stem bark while glycosides and quinones were not detected in the stem bark of Prosopis africana

Table 2: Some phytochemical components in stem bark extract of Prosopis africana $(\mathrm{g} / 100 \mathrm{~g})$

\begin{tabular}{|l|l|l|l|r|}
\hline Alkaloids & Tannins & Saponins & Phenols & Flavonoids \\
\hline $18.01 \pm 0.33$ & $2.51 \pm 0.07$ & $19.15 \pm 0.05$ & $1.70 \pm 0.07$ & $1.21 \pm 0.03$ \\
\hline
\end{tabular}

Values represent mean \pm SEM; $(n=3)$ 


\section{International Journal of Science and Research (IJSR) \\ ISSN (Online): 2319-7064}

Index Copernicus Value (2013): 6.14 | Impact Factor (2015): 6.391

Table 3: Antimicrobial susceptibility test showing zones of inhibition of the growth of the test organisms (mm)

\begin{tabular}{|l|l|l|l|l|}
\hline Prosopis africana & S. aureus & K. pneumoniae & N. gonorrhoeae & E. coli \\
\hline Zone of inhibition & 15 & 15 & - & 10 \\
\hline
\end{tabular}

- = Resistance of the test organism on the antimicrobial substance

Table 4: Minimum Inhibitory Concentration of Test substance

$-=$ No inhibition

\begin{tabular}{|l|c|c|c|c|}
\hline Prosopis africana & S. aureus & K pneumoniae & N. gonorrhoeae & E. coli \\
\hline Min. Inhibitory Conc. & 32 & 32 & - & 16 \\
\hline
\end{tabular}

Table 5: Minimum Bactericidal Concentration of Test substance

\begin{tabular}{|l|c|c|c|}
\hline S. aureus & $K$ pnewmoniae & $N$ gonorrhoeae & E. coli \\
\hline- & - & - & 64 \\
\hline
\end{tabular}

Table 6: The effect of aqueous stem bark extract of Prosopis africana on some biochemical parameters in rats

\begin{tabular}{|c|c|c|c|c|c|}
\hline Treatment. & Group1 Normal/control & Group2 200mg/kg & Group3 300mg/kg & Group4 400mg/kg & Group5 500mg/kg \\
\hline AST U/L & $75.0 \pm 0.6$ & $40.0 \pm 0.6^{*}$ & $29.3 \pm 0.9^{*}$ & $51.0 \pm 0.6^{*}$ & $73.0 \pm 1.0^{*}$ \\
\hline ALT U/L & $28.7 \pm 0.3$ & $22.0 \pm 0.6^{*}$ & $27.9 \pm 1.2$ & $32.7 \pm 0.7 \#$ & $33.7 \pm 0.9 \#$ \\
\hline ACP U/L & $22.7 \pm 0.3$ & $24.2 \pm 0.1 \#$ & $23.8 \pm 0.8$ & $26.5 \pm 0.3 \#$ & $26.3 \pm 0.7 \#$ \\
\hline ALP U/L & $162.8 \pm 1.6$ & $15.4 \pm 0.7 \#$ & $34.7 \pm 2.2 \#$ & $45.7 \pm 0.7 \#$ & $74.3 \pm 1.6 \#$ \\
\hline LDH U/L & $267.5 \pm 1.1$ & $322.8 \pm 1.1 \#$ & $754.4 \pm 1.7 \#$ & $739.0 \pm 2.3 \#$ & $313.3 \pm 1.8 \#$ \\
\hline Glucose mg/dl & $12.7 \pm 0.1$ & $93.8 \pm 0.8 \#$ & $41.2 \pm 7.3 \#$ & $25.8 \pm 6.5 \#$ & $90.6 \pm 0.9 \#$ \\
\hline Cholesterol mmol/l & $0.8 \pm 0.1$ & $0.6 \pm 0.1$ & $1.6 \pm 0.1 \#$ & $0.8 \pm 0.1$ & $0.7 \pm 0.0$ \\
\hline Total bilirubin $\mu \mathrm{mol} / \mathrm{l}$ & $2.8 \pm 0.1$ & $1.9 \pm 0.1^{*}$ & $1.5 \pm 0.2^{*}$ & $1.6 \pm 0.1^{*}$ & $6.3 \pm 0.3 \#$ \\
\hline Direct bilirubin $\mu \mathrm{mol} / \mathrm{l}$ & $2.0 \pm 0.1$ & $0.7 \pm 0.1$ & $1.3 \pm 0.1$ & $5.2 \pm 0.7 \#$ & $1.3 \pm 0.1$ \\
\hline Albumin g/l & $32.7 \pm 1.5$ & $46.6 \pm 0.7 \#$ & $29.7 \pm 0.9$ & $47.9 \pm 0.6 \#$ & $56.9 \pm 1.6 \#$ \\
\hline Total protein g/l & $127.9 \pm 4.0$ & $154.4 \pm 1.8 \#$ & $100.3 \pm 0.8^{*}$ & $110.0 \pm 3.3 *$ & $143.6 \pm 1.7 \#$ \\
\hline Urea mmol/l & $2.8 \pm 0.0$ & $4.9 \pm 0.7 \#$ & $1.6 \pm 0.0$ & $4.2 \pm 0.4 \#$ & $4.3 \pm 0.0 \#$ \\
\hline Creatinine mg/dl & $0.03 \pm 0.0$ & $0.7 \pm 0.0 \#$ & $0.1 \pm 0.0$ & $0.1 \pm 0.0 \#$ & $0.4 \pm 0.1 \#$ \\
\hline
\end{tabular}

Values represent mean \pm SEM $(n=3) \mathrm{p}<0.05) *=$ significantly lower than normal/control; \# = significantly higher than normal/control

$\mathrm{SEM}=$ Standard Error of Mean

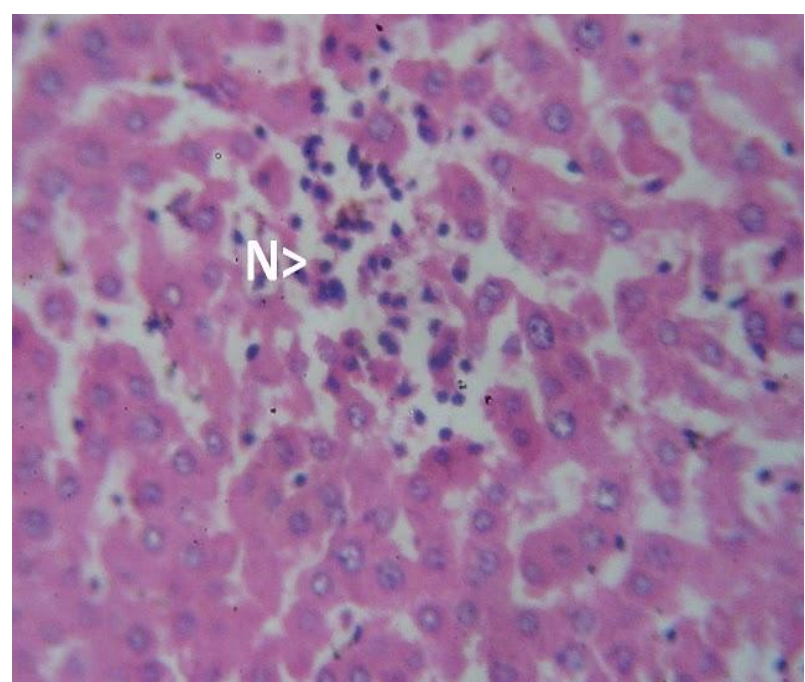

Plate 1: Liver: Focal area of necrosis $(\mathrm{N})$ with infiltrating neutrophils and macrophages (x760) of group 5 of Prosopis africana treated rats as compared to normal (Plates 2).

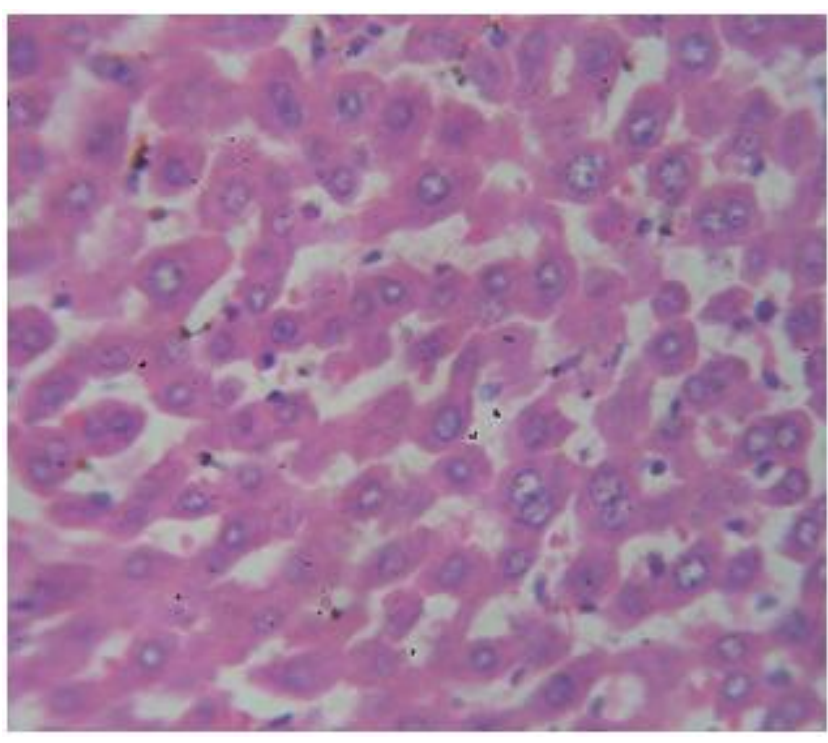

Plate 2: Liver (x760). Normal. 


\section{International Journal of Science and Research (IJSR) ISSN (Online): 2319-7064}

Index Copernicus Value (2013): 6.14 | Impact Factor (2015): 6.391

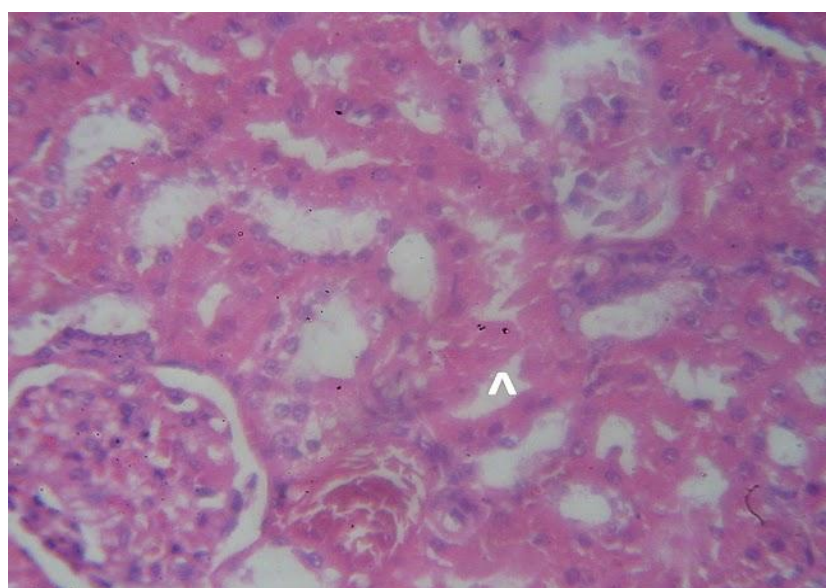

Plate 3: Kidney. Renal tubular necrosis \{ (arrowhead) (x760) \} of group 5 of Prosopis africana treated rats as compared to normal (Plate 4 below).

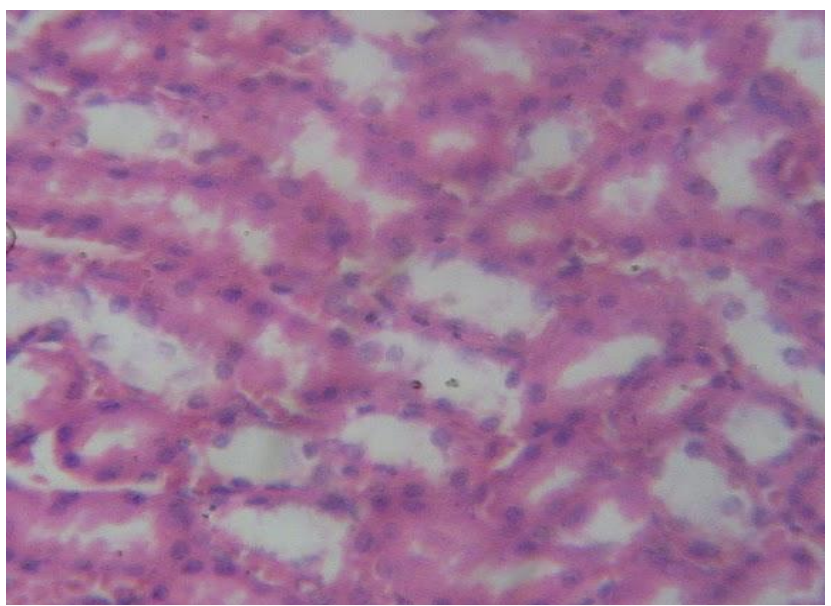

Plate 4: Kidney. Normal tubular epithelium (x760).

\section{Result and Discussion}

The phytochemical components detected in this work which includes alkaloids, tannins, saponins, phenols, anthraquinones, phlobatannins, and flavonoids could possibly contribute to the antimicrobial and physiological effects associated with the plant extract. The phytochemicals possibly contribute to the toxic and/or antioxidant/protective effects especially for the ones present in substantial amounts.

Some of the phytochemicals observed in this study have been implicated in the treatment of certain ailments and diseases such as diarrhoea, syphilis, and gonorrhoea (Maspalma, 1997). The effectiveness of the use of stem bark of Prosopis africana for the treatment of diarrhoeal disease in children by the local traditional healers could be due to the fact that they contain high concentrations of phytochemicals such as alkaloids and saponins. This tend to agree with what was reported by Ghoshal et al.,1996 that alkaloids have antidiarrhoeal effect which is probably due to their effect on transit time in the small intestine.

The effects of the crude plant extract on the test organisms as observed in this study showed high diameter of zones of inhibition produced by the crude stem bark extract of Prosopis africana on Staphylococcus aureus, Klebsiella pneumoniae and Escherichia coli.These observations could be attributed to the various antimicrobial (phytochemical components) substances detected in this study which have been implicated by various authors as strong antimicrobial agents which are toxic to microorganisms. Typical amongst the phytochemical components are phenols and phenolic compounds which have been reported by Mason and Wasserman (1987) as compounds whose toxicity to microorganisms include enzyme inhibition by the oxidized compounds possibly through reaction with sulphhydryl groups or through more non specific interactions with protein.

The Minimum Inhibitory Concentration (MIC) for each extract was determined against the four test organisms. Prosopis africana has an MIC of $32 \mu \mathrm{g} / \mathrm{ml}$ each for Staphylococcus aureus and Klebsiella pneumoniae and $16 \mu \mathrm{g} / \mathrm{ml}$ for Escherichia coli, while the Minimum Bactericidal Concentration (MBC) was $64 \mu \mathrm{g} / \mathrm{ml}$ for Escherichia coli. The effectiveness of the extract on the growth of the test organisms has manifested itself here as it did earlier in antimicrobial susceptibility test where the zones of inhibition were observed to be $15 \mathrm{~mm}$ each for Staphylococcus aureus and Klebsiella pneumoniae and $10 \mathrm{~mm}$ for Escherichia coli and none for Neisseria gonorrhoeae.

It was observed that AST/ALT levels were not significantly elevated, although some values were a little higher than the normal values. Although AST is localized in the liver, heart, muscles, kidneys, brain, pancreas, spleen and lungs, and ALT is localized in the liver, heart, muscles, and kidneys, however, the histological studies of the liver and kidney tissues actually predicts some degree of cell damage. The elevated level of Lactate Dehydrogenase (LDH) activity indicated some degree of cell damage to those tissues where the enzyme is localized. Also high serum LDH indicates liver congestion (Devlin, 1986). In fact, the level of this enzyme would suggest liver damage.

This study has shown increased serum glucose levels in the treated groups of the experimental animals as compared to normal/ control group, which were statistically significant $(p<0.05)$. The rise in serum glucose levels above normal could be due to the effects of the crude extract which might have affected the secretion of insulin by the islets of langerhans of the pancreas thereby reducing the rate of uptake of glucose by the body cells. Another possible cause might be due to leakage of glycogen into the blood as a result of liver cell injury.

This study has revealed that there was increase in serum level of cholesterol in the treated groups of experimental animals which was statistically significant $(p<0.05)$ in group three when compared with the normal/control group.

Serum urea and creatinine levels of the experimental animals showed significant increase as compared to normal/control group. Serum bilirubin indicated significant increase only in group of the experimental animals that received the highest dose. This rise in the levels of bilirubin could be as a result of the prolonged administration of the aqueous stem bark extracts which could contain some antimicrobial agents and antimicrobials or antibiotics are among the substances that could cause increase blood levels of bilirubin. Albumin 


\section{International Journal of Science and Research (IJSR) \\ ISSN (Online): 2319-7064 \\ Index Copernicus Value (2013): 6.14 | Impact Factor (2015): 6.391}

levels in the treated groups were significantly higher than what was observed in normal/control group. Overall, the results depicted a dose dependent behaviour of the effects of the stem bark extract of Prosopis africana on the experimental animals.

Histological examination of the tissues (liver and kidney) of the experimental animals revealed that the cells were damaged to some extent by the extract. The deleterious effects of the extract were observed to be more pronounced on the liver than the kidney. The finding that the liver cells were more affected by the aqueous extract than the kidney cells would suggest that the liver cells were more susceptible to the crude extract than the kidney cells. It is also possible that since the crude extract will first go the liver for detoxification, the hydrophilic conjugate may be less potent and will not have a drastic effect on the kidney, thus causing less damage to the kidney as observed in this study.

\section{References}

[1] Boham, A.B. and Kocipai, A.C. (1994). Flavonoids and condensed tannins from leaves of Hawaiian Vaccinium vaticulum and Vaccinium calycinium. Pacific Science, 48: 458-463.

[2] Bojang (2000). State of Forest Genetic Resources: National Forest Inventory. 1 - 5.

[3] Devlin, T. M. (1986). Text Book of Biochemistry With Clinical Correlations. 2nd Edition. A

[4] Wiley Medical Publication. John Wiley and sons. NewYork, Chichester, Brisbane, Toronto, Singapore. pp 164-165 and 262-327.

[5] Edward, A.I. (1983). Fundamentals of Microbiology. Addison Wesley Publishing Company, Inc. 691-693.

[6] Ghoshal, S., Krishna -Prasad, B.N., and Lakshmi, V. (1996). Antiamoebic activity of Piper longum fruits against Entamoeba histolytica in vitro and in vivo. $J$. Ethnopharmacol.50: 167-170.

[7] Harborne, J.B. (1973). Phytochemical Methods. Chapman and Hall London. 113.

[8] Mason, T.L., and Wasserman, B.P. (1987). Inactivation of red beet beta-glucan synthase by native and oxidized phenolic compounds. Phytochemistry. 26: 2197 - 2202.

[9] Maspalma, W.S. (1997). Taxonomic array of medicinal plants and their local uses in and around Yola Local Government Area of Adamawa State. pp. 17 - 19. B. Tech. thesis Dept. of Biol. Sci. F.U.T. Yola.

[10] Nester, E.W., Anderson, D.G., Roberts, C.E., Pearsall, N.N. and Nester, M.T. (2004).

[11] Microbiology: A human perspective. $4^{\text {th }}$ Edition. pp 518 $-519$.

[12] Obadoni, B.O. and Ochuko, P.O. (2001). Phytochemical studies and comparative efficacy of the crude extracts of some homeostatic plants in Edo and Delta States of Nigeria. Global Journal of Pure and Applied Sciences. 8: 203-208.

[13] Sofowora, A. (1982). Traditional Medicine in West Africa. John Wiley and Sons New York. Pp 256.

[14] Srivastava, J., Lambert, J. and Vietmeyer, N. (1996). Medicinal Plants: An Expanding Role in Development.World Bank Technical Paper No.320.World Bank. Washington DC.
[15] Trease, G.E., and Evans, W.C. (1989). A text book of pharmacognosy, $13^{\text {th }}$ edition. Bailliere Tindall Ltd. London.

[16] Van-Burden, T.P. and Robinson, W.C. (1981). Formation of complexes between proteins and tannic acid. J. Agric. Food Chem. 1: 107

[17] Wall, M.E., Krider, M.M., Krewson, C.F., Eddy, C.R., Wilaman, J.J., Cordell, D.S., and Gentry, H.S. (1954). Steroidal sapogenins XIII. Supplementay table of data for steroidal sapogenins VII, Agric Research services circ.Aic, 363: 17. 